\title{
HUBUNGAN ANTARA STATUS SOSIAL EKONOMI DAN PENGETAHUAN KESEHATAN LINGKUNGAN DENGAN PARTISIPASI IBU RUMAH TANGGA DALAM PEMELIHARAAN LINGKUNGAN SEHAT DI RUMAH SUSUN PENJERNIHAN JAKARTA PUSAT
}

Dra. Rosmawita Saleh, M.Pd

\begin{abstract}
The objective of the research is to study the relationship between, socio-economy status, knowledge of environment health and participation on healthy environment care mother's household of Rumah Susun Penjernihan Jakarta Pusat. The research was conducted at Jakarta Pusat from Februari to June 2001 with 72 respondents selected random sampling.

The research concludes that there are positive relationship between: (1) socio-economy status $\left(X_{1}\right)$ and participation on healthy environment care $(Y)$ with $r_{y 1}=.603$ and $Y=43.261+1.016 X_{1}$; (2) knowledge of environment health $\left(X_{2}\right)$ and participation on healthy environment care $(Y)$ with $r_{y 2}=.751$ and $Y=31.343+1.529 X_{2}$.

Furthermore, there is positive relationship between those two independent variables with participation on healthy environment care $(Y)$ with $r_{y .12}=.752$ and multiple regression $Y=31.251+1.447 X_{1}+0,087 X_{2}$.

Kata kunci : Status sosial ekonomi, kesehatan lingkungan, ibu rumah tangga, lingkungan sehat
\end{abstract}

\section{Pendahuluan}

Keluarga merupakan sebagai unit terkecil dari negara. Kumpulan dari keluarga akan membentuk suatu lapisan masyarakat dan selanjutnya lapisan-lapisan masyarakat tersebut bergabung dalam satu kelompok besar atau bangsa. Kesejahteraan suatu bangsa atau negara dengan demikian

Hubungan Antara Status Sosial Ekonomi Dan Pengetahuan Kesehatan Lingkungan Dengan Partisipasi Ibu Rumah Tangga Dalam Pemeliharaan Lingkungan Sehat Di Rumah Susun Penjernihan Jakarta Pusat (Rosmawita Saleh Dosen Jurusan Teknik Sipil FT- UNJ) 
sangat bergantung pada kesejahteraan keluarga atau rumah tangga. Pengukuran kesejahteraan sangat sulit dengan relatif sifatnya, bergantung pada individu. Selain itu, dipengaruhi pula oleh banyaknya faktor, antara lain keadaan sosial, ekonomi, dan budaya masing-masing daerah di mana tempat ia tinggal.

Ibu rumah tangga merupakan komponen keluarga yang turut mempengaruhi kesehatan lingkungan. Pendidikan yang ditempuh ibu rumah tangga memberikan dampak terhadap kesehatan keluarganya. Bagi seorang wanita, dapat menyelesaikan SD dan bahkan melanjutkan ke pendidikan yang lebih tinggi merupakan satu prestasi tertentu. Seperti pada kasus buta huruf, ternyata dalam hal pendidikan beberapa daerah di luar Jawa (Maluku, Aceh, Sumatera Barat dan Sumatera Utara) setelah berhasil memberikan banyak kesempatan kepada penduduk wanita untuk menyelesaikan pendidikan paling rendah SD. Persentase penduduk wanita yang tidak sekolah atau tidak/belum menamatkan SD pada keempat propinsi di atas adalah 27 persen, 28 persen, 31 persen dan 34 persen. Kesemuanya itu lebih rendah dari pada persentase untuk DKI Jakarta. Di Jawa Timur dan Jawa Tengah kurang lebih 1 di antara 2 penduduk wanita tidak sekolah; kalaupun sekolah, mereka tidak menyelesaikan sekolah dasarnya.

Upaya ibu rumah tangga untuk ikut andil di dalam pemeliharaan lingkungan sehat dapat berhasil apabila tidak memaksa kepada warga lainnya, dan tidak hanya memberikan keterangan. Dia menolong masyarakat sekitar untuk berpikir tentang masalah yang dihadapi, dan meminta mereka memikirkan jalan pemecahannya. Di sini warga lain akan turut berperan serta. Pada akhirnya mereka semua akan setuju untuk sama-sama bertindak untuk meningkatkan kepentingan kesejahteraan mereka.

Masyarakat seharusnya sadar bahwa penyakit itu memang ditentukan oleh berbagai faktor, antara lain perilaku masyarakat sendiri. Norma serta budaya akan menentukan gaya hidup masyarakat dan selanjutnya akan menciptakan keadaan lingkungan yang sesuai dengannya dan menimbulkan penyakit yang sesuai pula dengan gaya hidupnya tadi. Bagaimana sekelompok masyarakat memperlakukan lingkungan air, udara, dan sebagainya, akan mengakibatkan terjadinya penyakit yang sesuai pula dengan perilaku tadi. Jadi, untuk menjadi sehat tidak cukup hanya dengan 
pencegahan penyakit secara perseorangan, tetapi harus melihat dan mengelola masyarakat sebagai satu kesatuan bersama lingkungan hidupnya. Dengan demikian, kesehatan erat sekali hubungannya dengan sumberdaya sosial ekonomi dan semata-mata tidak hanya bergantung pada fasilitas kesehatan yang ada.

\section{Metode Penelitian}

Berdasarkan tujuan penelitian yang telah ditetapkan, disain penelitian ini menggunakan metode survei dengan teknik analisis regresi dan korelasi. Teknik korelasi digunakan untuk mengkaji hubungan antara status sosial ekonomi, pengetahuan tentang kesehatan lingkungan, dan partisipasi dalam pemeliharaan lingkungan sehat, secara sendiri-sendiri maupun secara bersama-sama. Di dalam penelitian ini tidak dikenakan perlakuan apapun terhadap responden, akan tetapi hanya diberikan tes dan kuesioner. Perangkat tes digunakan untuk memperoleh skor pengetahuan tentang kesehatan lingkungan. Perangkat kuesioner digunakan untuk memperoleh skor status sosial ekonomi dan partisipasi dalam pemeliharaan kesehatan lingkungan. Dengan demikian, diperoleh tiga macam faktor, yaitu skor pengetahuan yang dikotomis, serta skor status sosial ekonomi dan partisipasi yang menggunakan skala rentangan.

\section{Hasil Penelitian}

Dari hasil kuesioner partisipasi dalam pemeliharaan lingkungan sehat diperoleh skor tertinggi 79 dan skor terendah 52, skor rata-rata (Y) 65,79, modus (modus Y) 71, median (median Y) 68, simpangan baku (Sy) = 6,17 dan distribusi frekuensi yang dapat dilihat pada tabel 1 berikut ini.

Hubungan Antara Status Sosial Ekonomi Dan Pengetahuan Kesehatan Lingkungan Dengan Partisipasi Ibu Rumah Tangga Dalam Pemeliharaan Lingkungan Sehat Di Rumah Susun Penjernihan Jakarta Pusat (Rosmawita Saleh Dosen Jurusan Teknik Sipil FT- UNJ) 
Tabel 1. Distribusi Frekuensi Skor Partisipasi dalam Pemeliharaan Lingkungan Sehat $(\mathrm{Y})$

\begin{tabular}{|c|c|c|c|c|}
\hline No & Kelas Interval & $\mathrm{f}$ & $\mathrm{dr}$ & $\mathrm{fk}$ \\
\hline 1 & $52-55$ & 4 & 5,55 & 5,55 \\
2 & $56-59$ & 11 & 15,28 & 20,83 \\
3 & $60-63$ & 11 & 15,28 & 36,11 \\
4 & $64-67$ & 9 & 12,5 & 48,61 \\
5 & $68-71$ & 26 & 36,11 & 84,72 \\
6 & $72-75$ & 10 & 13,89 & 98,61 \\
7 & $76-79$ & 1 & 1,39 & $100^{*}$ \\
\hline
\end{tabular}

Keterangan :

$f=$ frekuensi absolut

$\mathrm{fr}=$ frekuensi relatif

$\mathrm{fk}=$ frekuensi kumulatif

* = pembulatan

Dari data yang ada diperoleh skor tertinggi 30 dan skor terendah 15, skor rata-rata $\left(X_{1}\right) 22,18$, simpangan baku $\left.S X_{1}\right) 3,66$, modus (modus $X_{1}$ ) 19 , median (median $X_{1}$ ) 22, serta distribusi frekuensi yang dapat dilihat pada tabel 2 berikut ini.

Tabel 2. Distribusi Frekuensi Skor Status Sosial Ekonomi $\left(\mathrm{X}_{1}\right)$

\begin{tabular}{|c|c|c|c|c|}
\hline No & Kelas Interval & $\mathrm{f}$ & $\mathrm{dr}$ & $\mathrm{fk}$ \\
\hline 1 & $15-16$ & 2 & 2,78 & 2,78 \\
2 & $17-18$ & 11 & 15,28 & 18,06 \\
3 & $19-20$ & 15 & 20,83 & 38,89 \\
4 & $21-22$ & 10 & 13,89 & 52,78 \\
5 & $23-24$ & 14 & 16,44 & 72,22 \\
6 & $25-26$ & 8 & 11,11 & 83,33 \\
7 & $27-28$ & 9 & 12,50 & 95,83 \\
8 & $29-30$ & 3 & 4,17 & $100^{*}$ \\
\hline
\end{tabular}

Keterangan :

$f=$ frekuensi absolut

$\mathrm{fr}=$ frekuensi relatif

$\mathrm{fk}=$ frekuensi kumulatif

* = pembulatan 
Kemudian dari hasil tes pengetahuan tentang kesehatan lingkungan $\left(\mathrm{X}_{2}\right)$ diperoleh skor tertinggi 29 dan skor terendah 17, skor rata-rata $\left(\mathrm{X}_{2}\right)$ 22,53, simpangan baku $\left(S_{x_{2}}\right) 3,03$, modus (modus $X_{2}$ ) 23, median (median $X_{2}$ ) 23, dan distribusi frekuensi yang dapat dilihat pada tabel 3 berikut ini.

Tabel 3. Distribusi Frekuensi Skor Pengetahuan tentang Kesehatan Lingkungan $\left(\mathrm{X}_{2}\right)$

\begin{tabular}{|c|c|c|c|c|}
\hline No & Kelas Interval & $\mathrm{f}$ & $\mathrm{dr}$ & $\mathrm{fk}$ \\
\hline 1 & $17-18$ & 7 & 9,72 & 9,72 \\
2 & $19-20$ & 14 & 19,44 & 29,16 \\
3 & $21-22$ & 13 & 18,06 & 47,22 \\
4 & $23-24$ & 18 & 25 & 72,22 \\
5 & $25-26$ & 12 & 16,67 & 88,89 \\
6 & $27-28$ & 7 & 9,72 & 98,61 \\
7 & $29-30$ & 1 & 1,39 & $100^{*}$ \\
\hline
\end{tabular}

Keterangan :

$f=$ frekuensi absolut

$\mathrm{fr}=$ frekuensi relatif

$\mathrm{fk}=$ frekuensi kumulatif

* = pembulatan

Jadi, hubungan antara pengetahuan tentang kesehatan lingkungan dan partisipasi dalam pemeliharaan lingkungan sehat tersebut berarti yang pembuktiannya dalam uji t.

Hubungan antara pengetahuan tentang kesehatan lingkungan $\left(X_{2}\right)$ dan partisipasi dalam pemeliharaan lingkungan sehat $(\mathrm{Y})$ memiliki koefisien korelasi sebesar $r=0,751$. Koefisien determinasi yang diperoleh menunjukkan bahwa $56,40 \%$ variasi partisipasi dalam pemeliharaan lingkungan sehat dapat dijelaskan dengan adanya variasi pengetahuan tentang kesehatan lingkungan.

Hubungan Antara Status Sosial Ekonomi Dan Pengetahuan Kesehatan Lingkungan Dengan Partisipasi Ibu Rumah Tangga Dalam Pemeliharaan Lingkungan Sehat Di Rumah Susun Penjernihan Jakarta Pusat (Rosmawita Saleh Dosen Jurusan Teknik Sipil FT- UNJ) 
Partisipasi pemeliharaan lingkungan sehat terhadap status sosial ekonomi dan pengetahuan tentang kesehatan lingkungan tersebut bermakna. Hal ini menunjukkan bahwa persamaan regresi yang diperoleh dapat digunakan sebagai syarat pengambilan kesimpulan yang berkenaan dengan kekuatan hubungan antara status sosial ekonomi dan pengetahuan tentang kesehatan lingkungan terhadap partisipasi dalam pemeliharaan lingkungan sehat.

\section{Kesimpulan}

Berdasarkan pada hasil penelitian yang telah didapat, maka dapat ditarik beberapa kesimpulan sebagai berikut:

Pertama, terdapat hubungan yang positif antara status sosial ekonomi dengan partisipasi dalam pemeliharaan lingkungan sehat. Kekuatan hubungan keduanya ditunjukkan oleh koefisien korelasi antara status sosial ekonomi dengan partisipasi dalam pemeliharaan lingkungan sehat sebesar $r$ $=0,603$. Koefisien korelasi tersebut dapat diartikan bahwa status sosial ekonomi memiliki daya jelas sebesar $36,36 \%$ terhadap variasi partisipasi dalam pemeliharaan lingkungan sehat.

Kedua, terdapat hubungan yang positif antara pengetahuan tentang kesehatan lingkungan dengan partisipasi dalam pemeliharaan lingkungan sehat. Kekuatan hubungan diantara keduanya ditunjukkan oleh koefisien korelasi antara pengetahuan tentang kesehatan lingkungan dengan partisipasi dalam pemeliharaan lingkungan sehat sebesar $r=0,751$. Koefisien korelasi tersebut menunjukkan bahwa pengetahuan tentang kesehatan lingkungan memberikan daya jelas terhadap variasi partisipasi dalam pemeliharaan lingkungan sehat.

Ketiga, terdapat hubungan yang positif antara pengetahuan dan status sosial ekonomi dengan partisipasi dalam pemeliharaan lingkungan sehat. Kekuatan hubungan ketiganya ditunjukkan oleh koefisien korelasi jamak ry.12 $=0,752$, yang bermakna pada 0,05. Di samping itu, hubungan jamak tersebut ditunjukkan oleh koefisien arah regresi $\beta 1=1,447, \beta 2=0,087$ dan konstanta sebesar 31,251 yang signifikan pada 0,05. Atas dasar hasil pengujian hipotesis terse but, dapat disimpulkan bahwa partisipasi dalam pemeliharaan 
lingkungan sehat dapat diprediksi atas dasar pengetahuan tentang kesehatan lingkungan dan status sosial ekonomi.

\section{Saran}

Berdasarkan kesimpulan dan implikasi di atas, dapat diajukan beberapa saran berikut :

Pertama, bagi penghuni perumahan susun khususnya Perumahan Susun Penjernihan Jakarta Pusat, hasil penelitian ini menunjukkan bahwa terdapat hubungan yang positif antara pengetahuan tentang kesehatan lingkungan dengan partisipasi dalam pemeliharaan lingkungan sehat. Sementara itu, rata-rata pengetahuan ibu rumah tangga sudah cukup baik. Dengan demikian, bagi ibu rumah tangga peningkatan pengetahuan tentang kesehatan lingkungan ini harus tetap dilakukan agar tetap tercipta lingkungan sehat. Peningkatan pengetahuan tersebut dapat lebih menarik jika dikelola secara apik dengan metode yang tidak membosankan, monoton, maupun yang menggurui.

Kedua, bagi peneliti lain, perlu dilakukan penelitian lebih lanjut yang menjajagi variabel-variabel yang juga mempengaruhi partisipasi ibu rumah tangga. Variabel tersebut misalnya variabel psikologis yang lain berupa sikap, motivasi, maupun inovasi mereka.

Ketiga, bagi para pengembang atau developer, perlu dipikirkan suatu model pengembangan bangunan rumah tinggal yang memungkinkan partisipasi masyarakat dalam pemeliharaan lingkungan sehat. Jika pertama kali dibangun lingkungan perumahan susun sudah memenuhi syarat rumah sehat maka perlu dipikirkan kelanggengannya.

\section{Daftar Pustaka}

Barnhouse, Ruth Tiffany. Identity, Define Yourself in Creative Ways, Know Yourself in the Image of God, terjemahan LG Lunandi Identitas Wanita Bagaimana mengenal dan membentuk Citra Diri. Yogyakarta Kanisius, 1988.

Hubungan Antara Status Sosial Ekonomi Dan Pengetahuan Kesehatan Lingkungan Dengan Partisipasi Ibu Rumah Tangga Dalam Pemeliharaan Lingkungan Sehat Di Rumah Susun Penjernihan Jakarta Pusat (Rosmawita Saleh Dosen Jurusan Teknik Sipil FT- UNJ) 
Davis, Keith. Human Relation at Work. Tokyo: Tosho Printing Co. Ltd. 1962.

Encyclopedia of Social Science. New York: Macmillan Company, 1989.

Entjang, Indan. IImu Kesehatan Masyarakat. Bandung Alumni, 1982.

Ihromi, T.O. (ed), Kajian Wanita dalam Pembangunan. Jakarta: Yayasan Obor, 1995.

Koentjaraningrat dan A.A. Loedin (ed). Ilmu-ilmu Sosial dalam Pembangunan Kesehatan, Jakarta: Gramedia, 1985.

Kornblum, William. Sociology in a Change World. New York: Holt Rinehart and Einston, 1988.

Muzaham. Fauzi, Memperkenalkan Sosiologi Kesehatan. Jakarta: UI Press, 1995.

Notoatmodjo, Soekidjo. Pengantar Pendidikan Kesehatan dan IImu Perilaku Kesehatan. Yogyakarta: Andi Offset, 1993.

Parelius, Robert James dan Ann Parker. The Sociology of Education. New Jersey: Prentice Hall, 1992.

Slamet, Juli Soemirat. Kesehatan Lingkungan. Yogyakarta: Gajah Mada University Press, 1996.

Sudarsono, F.X. "Pengukuran Status Sosial Ekonomi dan Permasalahannya", Populasi Nomor 2, Volume 1, Tahun 1990.

Sudjana. Teknik Analisis Regresi dan Korelasi. Bandung: Tarsito, 1992.

WHO. Education for health: A Manual o Health Education in Primary Health Care terjemahan Ida Bagus Tjitarsa Pendidikan Kesehatan Pedoman Pelayanan Kesehatan Dasar. Bandung: Penerbit ITB, 1992. 